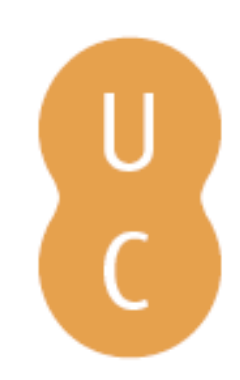

\title{
nombalina
}

\section{Religiões proféticas e religiões místicas}

\author{
Autor(es): $\quad$ Correia, Carlos João
}

Publicado por: Imprensa da Universidade de Coimbra

URL

persistente: $\quad$ URI:http://hdl.handle.net/10316.2/30089

DOI: $\quad$ DOI:http://dx.doi.org/10.14195/978-989-26-0310-0_8

Accessed : $\quad$ 26-Apr-2023 12:38:37

A navegação consulta e descarregamento dos títulos inseridos nas Bibliotecas Digitais UC Digitalis, UC Pombalina e UC Impactum, pressupõem a aceitação plena e sem reservas dos Termos e Condições de Uso destas Bibliotecas Digitais, disponíveis em https://digitalis.uc.pt/pt-pt/termos.

Conforme exposto nos referidos Termos e Condições de Uso, o descarregamento de títulos de acesso restrito requer uma licença válida de autorização devendo o utilizador aceder ao(s) documento(s) a partir de um endereço de IP da instituição detentora da supramencionada licença.

Ao utilizador é apenas permitido o descarregamento para uso pessoal, pelo que o emprego do(s) título(s) descarregado(s) para outro fim, designadamente comercial, carece de autorização do respetivo autor ou editor da obra.

Na medida em que todas as obras da UC Digitalis se encontram protegidas pelo Código do Direito de Autor e Direitos Conexos e demais legislação aplicável, toda a cópia, parcial ou total, deste documento, nos casos em que é legalmente admitida, deverá conter ou fazer-se acompanhar por este aviso.

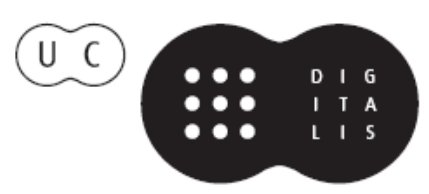




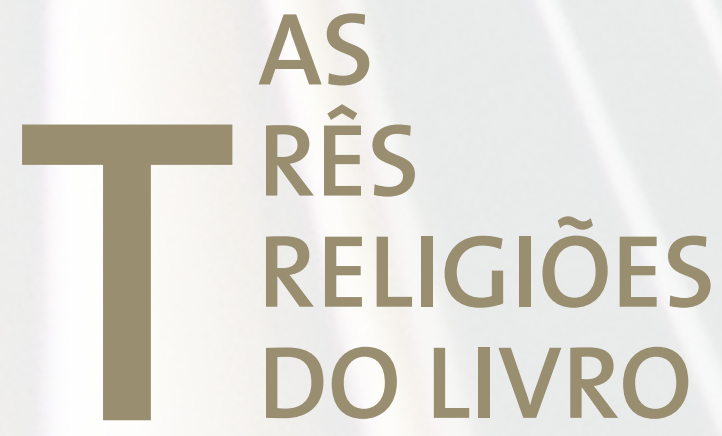

Anselmo Borges

João Gouveia Monteiro

COORDENAÇÃO 
Carlos João Correia 24

\section{RELIGIÕES PROFÉTICAS E RELIGIÕES MÍSTCAS}

A distinção conceptual entre religiões proféticas e místicas constitui um dos traços fundamentais da obra de Robert Charles Zaehner, antigo Professor de Ética e Religiões Orientais da Universidade de Oxford. No seu estudo comparativo das religiões, intitulado At Sundry Times (1958), sustenta a necessidade de se descobrir os pontos de contacto, mas também as enormes diferenças entre as religiões de raiz semítica, designadas como proféticas, e as religiões místicas, provenientes da antiga civilização indiana.

O título da obra referida traduz bem o sentido da sua investigação; com efeito, a expressão "at sundry times" corresponde ao início da epístola de São Paulo aos Hebreus, na qual nos é dito: "muitas vezes e de modos diversos falou Deus”. Com esta referência, não se pense que Zaehner está interessado em defender a ideia de que todas as religiões tinham uma natureza comum assente na devoção a um Deus pessoal. A finalidade desta obra era duplamente distinta: por um lado, consagrar o estudo comparativo das religiões, denunciando o preconceito da atitude prosélita de quem vê nas religiões distintas da sua apenas a expressão confusa da sua própria espiritualidade; tal atitude deixa-se traduzir, por exemplo, na tese de que as religiões orientais não seriam propriamente religiões, mas antes formas sapienciais de viver. Mas, por outro lado, Zaehner quer distanciar-se de uma corrente de pensamento, muito influente no século xx, conhecida como "escola tradicionalista", defensora de uma filosofia ou religião perene.

\footnotetext{
24 Professor de Filosofia das Religiões da Faculdade de Letras da Universidade de Lisboa.
} 
A designação de philosophia perennis, de raiz renascentista, retomada por Leibniz, tornou-se subitamente muito popular no Ocidente nos finais dos anos 40, nomeadamente, quando o escritor Aldous Huxley, o autor do célebre romance Admirável Mundo Novo (Brave New World, 1932), aderiu aos princípios fundamentais dessa escola, adesão consubstanciada no livro A Filosofia Perene (The Perennial Philosophy, 1945). Um dos membros dessa escola - o filósofo suíço Frithjof Schuon - apresenta-nos de uma forma sintética os princípios essenciais da visão do mundo que lhe está subjacente e que designou explicitamente por religião perene (religio perennis): "A função essencial da inteligência humana é o discernimento entre o real e o ilusório ou, se se preferir, entre o permanente e o impermanente, sendo função essencial do querer atingir o permanente ou o real." Acrescenta Schuon, "este discernimento e este alcançar é a quintessência de toda a espiritualidade”, estando "presente em todo o património espiritual da humanidade, podendo assim falar-se de religio perennis." Segundo esta escola, a Índia antiga tinha exactamente a mesma visão, designando-a através de uma expressão em sânscrito, sanátana dharma, i.é, literalmente, "ordem eterna", símbolo de uma verdade que transcende os limites do tempo e do espaço.

Zaehner, profundo conhecedor das religiões de raiz semítica e das religiões cultivadas na antiga Índia, discordava radicalmente de ambas as atitudes, seja daqueles para quem a genuína religião só pode ser a sua, seja dos que, como Huxley, Coomaraswamy e Schuon, procuravam encontrar uma visão monista e identitária de toda a espiritualidade humana. Com efeito, o que estava em jogo era o reconhecimento do estudo comparado das religiões, que exige, como sua condição prévia, o reconhecimento da pluralidade, i.é, da legitimidade de múltiplas formas profundamente distintas de expressão religiosa, em particular, aquelas que são subsumidas como "religiões proféticas” (Judaísmo, Cristianismo e Islão) e as que se constituem como "religiões místicas" (Hinduísmo, Budismo e Daoismo). Em termos sintéticos, pode-se dizer que, para Zaehner, nas religiões proféticas, a voz divina é proferida pelos profetas aos seres humanos, enquanto nas religiões místicas, de matriz indiana, o cerne da sua busca espiritual se encontra na obtenção de uma experiência de identificação entre o âmago da alma e o eterno. Citemos Zaehner: 
"O místico vê-se a si mesmo como fundido ou unificado no eterno, mas o profeta sabe - ou pensa - que o Eterno fala através dele ao mundo. Não é uma vítima passiva de um estado sobrenatural; ele é, voluntariamente ou não, o porta-voz de um poder assombroso que, através da profecia, formula as mais elevadas exigências ao ser humano" (At Sundry Times, 26).

Seria relativamente fácil mostrar os limites desta mesma contraposição religiosa; afinal, tanto o misticismo como o profetismo estão presentes quer nas religiões ocidentais quer nas orientais. As religiões indianas conhecem bem a importância da palavra revelada (shruti), literalmente, aquela que é "escutada" e que se consubstancia na literatura védica; por sua vez, as religiões ditas proféticas conheceram, em muitos momentos da sua história, a força e o impacto do misticismo (cf., a título de exemplo, a cabala do Zohar e de Isaac de Luria no Judaísmo; as visões místicas de São João da Cruz e de Santa Teresa de Ávila, ambos Doutores da Igreja Cristã; assim como a importância do movimento místico dos Sufis no Islão). Mesmo em termos de catalogação, perguntamo-nos se não é mais fina a distinção feita pelo teólogo Hans Küng entre religiões "proféticas", "místicas" e "sapienciais", sendo estas últimas cultivadas na China por doutrinas como a Confucionista, cuja forma paradigmática se expressa no imperativo dos Analectos [colectânea de textos de Confúcio]: "não faças aos outros o que não queres que te façam a ti".

A meu ver, mais importante do que estabelecer etiquetas identificadoras, importa pensar os pontos de identidade e de diferença entre as religiões cultivadas no Ocidente e na Ásia. Para esse efeito, ir-me-ei socorrer, num primeiro momento, das teses formuladas por Yehezkel Kaufmann na sua obra clássica, História da Religião de Israel (1960). Segundo este historiador das religiões, a constituição do monoteísmo representou um momento único na história do pensamento humano. Como o autor sublinha - tese que é reafirmada nos nossos dias por Karen Armstrong -, a questão do monoteísmo nunca foi um problema de número, i.é, transcende a mera troca da crença em múltiplos deuses por um só. O monoteísmo puro, cuja revelação apenas se dá tardiamente na Bíblia, no Segundo Isaías - "não há outro Deus além de mim" (Is 46:1), implicou uma série de princípios que rompiam com as raízes do paganismo tradicional. Que princípios eram esses? Em primeiro lugar, as religiões pagãs acreditavam 
num reino "metadivino", i.é, num reino do ser prévio à própria existência dos deuses. Como nos diz Kaufmann: "mesmo os deuses são representados como tendo de apelar para forças metadivinas para superar as suas limitações pré-determinadas." Esse domínio metadivino poderia ser perspectivado sob diferentes formas, como, por exemplo, o oceano, o caos, as trevas, o espírito, a luz, o destino, o sangue, entre tantos exemplos. Na visão pagã do mundo, esse reino metadivino era, em muitos casos, tão misterioso para os deuses como para os homens. Por sua vez, o paganismo implica uma teogonia, i.é, uma explicação de como surgiram os diferentes deuses, podendo, nalguns casos, os seres divinos morrerem ou mesmo reencarnarem em diferentes seres vivos. Todo o poder que os deuses e os homens possuíam derivava da magia, a saber, da sua capacidade de manipular elementos e substâncias, sendo o rito a forma por excelência dessa manipulação mágica; em última instância, os seres humanos podiam usar esse conhecimento mágico do reino metadivino para condicionar a acção dos deuses e das forças da natureza. O reino metadivino, nas religiões pagãs, seja ele pensado como "sangue", "água” ou "destino", está para lá do bem e do mal, sendo os valores entidades reais, substanciais que se digladiam entre si (deuses e demónios).

Segundo Kaufmann, a revolução monoteísta pôs em causa todos estes princípios. Em termos sintéticos: $1^{\circ}$ Deus é a fonte de todo o ser e não está subordinado a nada; $2^{\circ}$ não existe qualquer teogonia, na medida em que Deus simplesmente é, ou seja, não cresce, não tem idade, não tem identidade ou parceiros sexuais e não morre; $3^{\circ}$ transcende a natureza, pois não existe nenhuma força natural com a qual o possamos identificar; $4^{\circ}$ Deus não pode ser manipulado, coagido a agir contra a sua vontade, o que significa que a religião monoteísta não conhece o rito, mas apenas o culto e a celebração; $5^{\circ}$ não existem entidades maléficas, estando o mal contido nas decisões inerentes à acção humana. Segundo Kaufmann, este era o ideário fundamental do monoteísmo puro que, apenas por razões de expressão simbólica - ou então de contacto com outras civilizações, como foi o caso da mundovisão babilónica -, pôde, por vezes, ser confundido com as religiões pagãs. A única relação possível entre o humano e o divino é, por um lado, a autopercepção terrível de Isaías de que está perdido em face de Deus, mas, ao mesmo tempo, a reafirmação crucial de "Eis-me" (bimeni) quando 
apelado. Esta resposta incondicional, este "eis-me", não é arrebatamento extático em direcção ao reino de Deus, mas a acção moral que responda à justiça exigida ao "órfão", ao "pobre" e à "viúva", em que seja o amor (hesed) e não o sacrifício ou holocausto ( $A m$ 5:21-25) o móbil das acções. A face de Deus da Bíblia judaica, do judaísmo talmúdico, é nitidamente ética.

Poder-se-á dizer que as religiões da Índia são ainda resquícios do paganismo que, em determinados momentos da história, foi vigente em todo o mundo e, em certa medida, ainda está bem vivo no mundo tecnológico contemporâneo? Sem dúvida que em certos textos mais primitivos dos Vedas é possível descobrir, aqui e ali, resquícios dessa mesma mentalidade; mas o mesmo se poderia dizer do Génesis. A novidade da civilização antiga da Índia foi a de ter reformulado - e não apenas rompido - com a crença num universo metadivino, neutro e omnipotente. A Índia antiga promoveu uma desmitologização do reino metadivino, conseguindo pensá-lo para lá do conjunto de elementos e forças naturais com que foi anteriormente identificado. E, deste modo, obtém uma visão monoteísta do divino, de alguma forma mais radical, na medida em que a vontade, a dimensão pessoal, são apenas predicados, entre muitos outros, desse mesmo reino do ser. Por sua vez, sem se abolir a transcendência, esta última nunca é posicionada sob o registo da separação entre o divino - agora designado como "realidade absoluta ou incondicionada" (em sânscrito: Brahman) - e as suas múltiplas formas de expressão natural. Deus, o Eterno ou Absoluto, não é a Natureza, mas não está divorciado dela. Como o Deus de Israel, Brahman, a realidade eterna e absoluta, está para lá de todos os seres e não está subordinada a nada; como no Deus dos profetas, Brahman não conhece teogonia, pois o absoluto, em si próprio, não tem génese, não conhece identidade sexual e não está subordinado à lei da morte. As diferentes divindades que povoam o imaginário hindu são claramente assumidas como "pontos de vista" (darshanas) do eterno retorno de Brabman sobre o seu próprio ser. Por sua vez, Brahman está integralmente presente em cada "mente viva" e daí a canónica formulação hindu da identidade entre a realidade absoluta e o espírito pessoal de cada ser.

Esta reformulação do paganismo numa forma distinta de conceber o divino tem - por mais paradoxal que possa parecer - a sua expressão mais 
radical em duas religiões, tantas vezes referidas como ateias, a saber, o budismo e o daoismo. Ouçamos as palavras de Gotama, o Buda:

"Monges, há um não-nascido, um não-efémero, um não-composto, um incondicionado sem o qual o nascido, o efémero, o construído, o condicionado não poderiam ser experienciados; mas monges, porque há um não-nascido, um não-efémero, um não-composto, um incondicionado, então o nascido, o efémero, o construído, o condicionado pode ser experienciado."

Por sua vez, relembremos as primeiras palavras do filósofo chinês Laozi no Dao de Jing (antigamente conhecido por Tao Te King):

"O Dao [nome equivalente chinês para Brahman] que pode ser expresso não é o Dao constante e permanente. O nome que pode ser nomeado não é o nome constante e permanente. O começo do céu e da terra é concebido a partir do que não tem nome; concebido como o que tem nome é, por sua vez, a mãe de todas as coisas."

Podemos, assim, defender que tem sentido falar-se de religiões proféticas de matriz essencialmente ética; como tem igualmente significado defender a ideia de religiões místicas que apontam para a exigência do espírito humano se libertar do condicionado, do efémero e, deste modo, atingir a realidade eterna, infinita, que existe, em si e por si, no âmago de todos os seres vivos. Concluímos, assim, com a tese de que mais importante do que contrapor o místico e o profético, importa, sim, compreendê-los, permitindo diálogos que ainda hoje não foram suficientemente aprofundados.

Dizia o poeta, mas também filósofo, T.S. Eliot, no seu célebre ensaio sobre a cultura: "podemo-nos perguntar se aquilo a que chamamos cultura e aquilo a que chamamos religião de um povo não são aspectos diferentes do mesmo, sendo a cultura a incarnação da religião de um povo". Se a tese de Eliot for verdadeira, podemo-nos legitimamente interrogar - neste mundo globalizado - qual o autêntico sentido da religião e da cultura. Qualquer que seja a resposta, ela passará sempre pelo diálogo entre o Ocidente e o Oriente, entre as religiões ditas proféticas e místicas. 